\title{
Development of Powdery Mildew Fungus on Cucumber Leaves Acclimatized to Different $\mathrm{CO}_{2}$ Concentrations
}

\author{
Kaori Itagaki, Toshio Shibuya ${ }^{1}$, Motoaki Tojo, Ryosuke Endo, \\ and Yoshiaki Kitaya \\ Graduate School of Life and Environmental Sciences, Osaka Prefecture \\ University, Gakuen-cho 1-1, Naka-ku, Sakai 599-8531, Japan
}

Additional index words. $\mathrm{CO}_{2}$ starvation, Cucumis sativus, plant-pathogen interactions, Podosphaera xanthii, susceptibility

\begin{abstract}
The present study evaluated the development of powdery mildew fungus (Podosphaera xanthii) on leaves of cucumber (Cucumis sativus L.) acclimatized to different $\mathrm{CO}_{2}$ concentrations $\left(\left[\mathrm{CO}_{2}\right]\right)$ to examine plant-pathogen interactions under the wide range of $\left[\mathrm{CO}_{2}\right]$ that can occur in greenhouse cultivation. Seedlings of resistant and nonresistant cultivars were acclimatized to reduced $\left(200 \mu \mathrm{mol} \cdot \mathrm{mol}^{-1}\right)$, ambient $\left(400 \mu \mathrm{mol} \cdot \mathrm{mol}^{-1}\right)$, or elevated $\left(1000 \mu \mathrm{mol} \cdot \mathrm{mol}^{-1}\right)\left[\mathrm{CO}_{2}\right]$. Powdery mildew spores were inoculated onto the adaxial surface of cotyledons or first true leaves, and colonization was measured after 7 days. Colony density decreased as acclimatization $\left[\mathrm{CO}_{2}\right]$ increased at the cotyledon stage but increased at the first-true-leaf stage in both cultivars. This result implies that when the effects of $\left[\mathrm{CO}_{2}\right]$ on plant-pathogen interactions are described, growing stage must be specified. The acclimatization $\left[\mathrm{CO}_{2}\right]$ was correlated positively with leaf mass per area, dry matter content, and carbon $(C)$ content and negatively with nitrogen $(N)$ content at both stages. Therefore, these leaf properties could not explain the changes in host-plant susceptibility between stages. The effect of acclimatization $\left[\mathrm{CO}_{2}\right]$ was greater on the resistant cultivar than on the nonresistant cultivar, indicating that the resistant cultivar was more responsive.
\end{abstract}

The $\left[\mathrm{CO}_{2}\right]$ in greenhouse cultivation during daylight hours is often lower than the atmospheric level, possibly as low as $200 \mu \mathrm{mol} \cdot \mathrm{mol}^{-1}$ when ventilation is limited (Kläring et al., 2007; Sánchez-Guerrero et al., 2005). In such cases, $\mathrm{CO}_{2}$ fertilization can avoid the inhibition of photosynthesis and effects on plant growth (Mortensen, 1987; Nilsen et al., 1983). Low $\left[\mathrm{CO}_{2}\right]$ might also affect plant characteristics such as resistance to biotic stresses, because when photosynthesis is limited, plants might not allocate sufficient resources to defense responses (Bazzaz et al., 1987; Bryant et al., 1983). Resistance to biotic stresses might have been lower under the lower ambient $\left[\mathrm{CO}_{2}\right]$ levels of the past (Sage and Cowling, 1999), but this possibility has not been well studied experimentally.

Received for publication 3 Aug. 2015. Accepted for publication 23 Sept. 2015.

Kaori Itagaki is a research fellow of the Japan Society for the Promotion of Science (JSPS). This research was supported by a Grant-in-Aid for JSPS Fellows (KAKENHI 2510391) and a Grant-in-Aid for Scientific Research (B) (General) (KAKENHI 24380140, KAKENHI 15H04575) from the JSPS. We are grateful to Yukio Sato for helpful suggestions and discussion.

${ }^{1}$ Corresponding author. E-mail: shibuya@envi. osakafu-u.ac.jp.
The effects of $\left[\mathrm{CO}_{2}\right]$ on the development of foliar diseases has been investigated at $\left[\mathrm{CO}_{2}\right]$ from atmospheric $\left(\approx 380 \mu \mathrm{mol} \cdot \mathrm{mol}^{-1}\right)$ to higher $\left(650-800 \mu \mathrm{mol} \cdot \mathrm{mol}^{-1}\right)$ levels, covering the possible range of $\left[\mathrm{CO}_{2}\right]$ expected in the future. Several studies reported that higher $\left[\mathrm{CO}_{2}\right]$ suppresses the development of foliar diseases (e.g., powdery mildew, blight, leaf spot) in some plant species through changes in leaf properties that defend against infection and the development of pathogens (Manning and Tiedemann, 1995; Mathur et al., 2013; McElrone et al., 2005; Strengbom and Reich, 2006), although conflicting results were also reported (Kobayashi et al., 2006; Lake and Wade, 2009). It had been suggested that a greater leaf mass per area and lower $\mathrm{N}$ content and the consequent increase in $\mathrm{C}: \mathrm{N}$ ratio of host plant at higher $\left[\mathrm{CO}_{2}\right]$ suppress the development of foliar diseases. Physiological responses opposite to those observed under higher $\left[\mathrm{CO}_{2}\right]$ are likely to occur under lower $\left[\mathrm{CO}_{2}\right]$ because of the reduction in $\mathrm{C}$ uptake due to photosynthetic reduction (Gerhart and Ward, 2010; Sage, 1995).

The present study evaluated the development of powdery mildew, a foliar disease caused by the fungus $P$. xanthii, on leaves of cucumber ( $C$. sativus L.) acclimatized to $\left[\mathrm{CO}_{2}\right]$ levels both lower and higher than atmospheric, and investigated the relationships between susceptibility and leaf properties.
The goal was to evaluate plant-pathogen interactions under the low to high $\left[\mathrm{CO}_{2}\right]$, which can occur in greenhouse cultivation.

\section{Materials and Methods}

Plant materials and growth conditions. The trials used the nonresistant cultivar Hokushin (Takii \& Co. Ltd., Kyoto, Japan) and the resistant cultivar Tokiwa 333 (Tokiwa Co. Ltd., Saitama, Japan). The study examined susceptibility and leaf properties of host-plant in both cotyledons and first true leaves, in which leaf structures and functions differ, and so different responses to $\left[\mathrm{CO}_{2}\right]$ are likely.

Seeds were sown in vermiculite in plastic pots ( $60 \mathrm{~mm}$ diameter, $55 \mathrm{~mm}$ height), which were placed in growth chambers (Ikeya Co. Ltd., Kashiba, Japan) maintained at reduced $\left(\approx 200 \pm 20 \mu \mathrm{mol} \cdot \mathrm{mol}^{-1}\right)$, ambient $(\approx 400 \pm$ $\left.20 \mu \mathrm{mol} \cdot \mathrm{mol}^{-1}\right)$, or elevated $(\approx 1000 \pm$ $\left.20 \mu \mathrm{mol} \cdot \mathrm{mol}^{-1}\right)\left[\mathrm{CO}_{2}\right]$ during the light period. The $\left[\mathrm{CO}_{2}\right]$ was controlled by a $\mathrm{CO}_{2}$ controller (Ace Point Systems Inc., Osaka, Japan) connected to an infrared gas analyzer $\left(\mathrm{CO}_{2}\right.$ Engine K30; SenseAir, Delsbo, Sweden). When the $\left[\mathrm{CO}_{2}\right]$ decreased below the set level, $\mathrm{CO}_{2}$ was supplied from a gas cylinder. For the reduced $\left[\mathrm{CO}_{2}\right]$ treatment, $\mathrm{CO}_{2}$ absorbent (soda-lime; Hayashi Pure Chemical Ind. Ltd., Osaka, Japan) was placed in the growth chamber to remove $\mathrm{CO}_{2}$ continuously. The $\left[\mathrm{CO}_{2}\right]$ during the dark period was not controlled, but did not increased drastically; the maximum $\left[\mathrm{CO}_{2}\right]$ during the dark period was $\approx 300,600$, and $1400 \mu \mathrm{mol} \cdot \mathrm{mol}^{-1}$ for reduced, ambient, and elevated $\left[\mathrm{CO}_{2}\right]$ treatment, respectively. The growth chambers were maintained at an air temperature of $28{ }^{\circ} \mathrm{C}$, a relative humidity of $50 \%$, and a photosynthetic photon flux $(P P F)$ of $350 \mu \mathrm{mol} \cdot \mathrm{m}^{-2} \cdot \mathrm{s}^{-1}$ provided by fluorescent lamps (FPL55EX-N; Panasonic Corp., Kadoma, Japan) under a light:dark cycle of 16:8 $\mathrm{h}$. The pots were placed in nutrient solution (A-type recipe of OAT Solution; OAT Agrio Co. Ltd., Tokyo, Japan) 5 to $10 \mathrm{~mm}$ deep.

Inoculation test at the cotyledon stage. Plants were inoculated at the cotyledon stage in three sequential trials with 'Hokushin' and one trial with 'Tokiwa 333', simultaneous with the third trial of 'Hokushin'. The number of replicates was $n=10$ for each trial.

When the cotyledons had expanded and the first true leaf had begun to emerge, 10 seedlings in each treatment were sprayed with a suspension of $P$. xanthii spores onto the adaxial surface of the cotyledons (Itagaki et al., 2014; Shibuya et al., 2011). The concentrations were $3.03 \times 10^{6}$ spores $/ \mathrm{mL}$ in trial $1,0.89 \times 10^{6}$ spores $/ \mathrm{mL}$ in trial 2 , and $3.05 \times 10^{6}$ spores $/ \mathrm{mL}$ in trial 3 . The seedlings were then placed in another growth chamber (LPH-220SP; Nippon Medical \& Chemical Instruments Co., Ltd., Osaka, Japan) maintained as before but with a PPF of $200 \mu \mathrm{mol} \cdot \mathrm{m}^{-2} \cdot \mathrm{s}^{-1}$ provided by fluorescent lamps (FL20SEX-N-HG; NEC Lighting Ltd., Tokyo, Japan). The $\left[\mathrm{CO}_{2}\right]$ in this chamber was not controlled and was $\approx 400$ $\mu \mathrm{mol} \cdot \mathrm{mol}^{-1}$ during the photoperiod. Colonies 


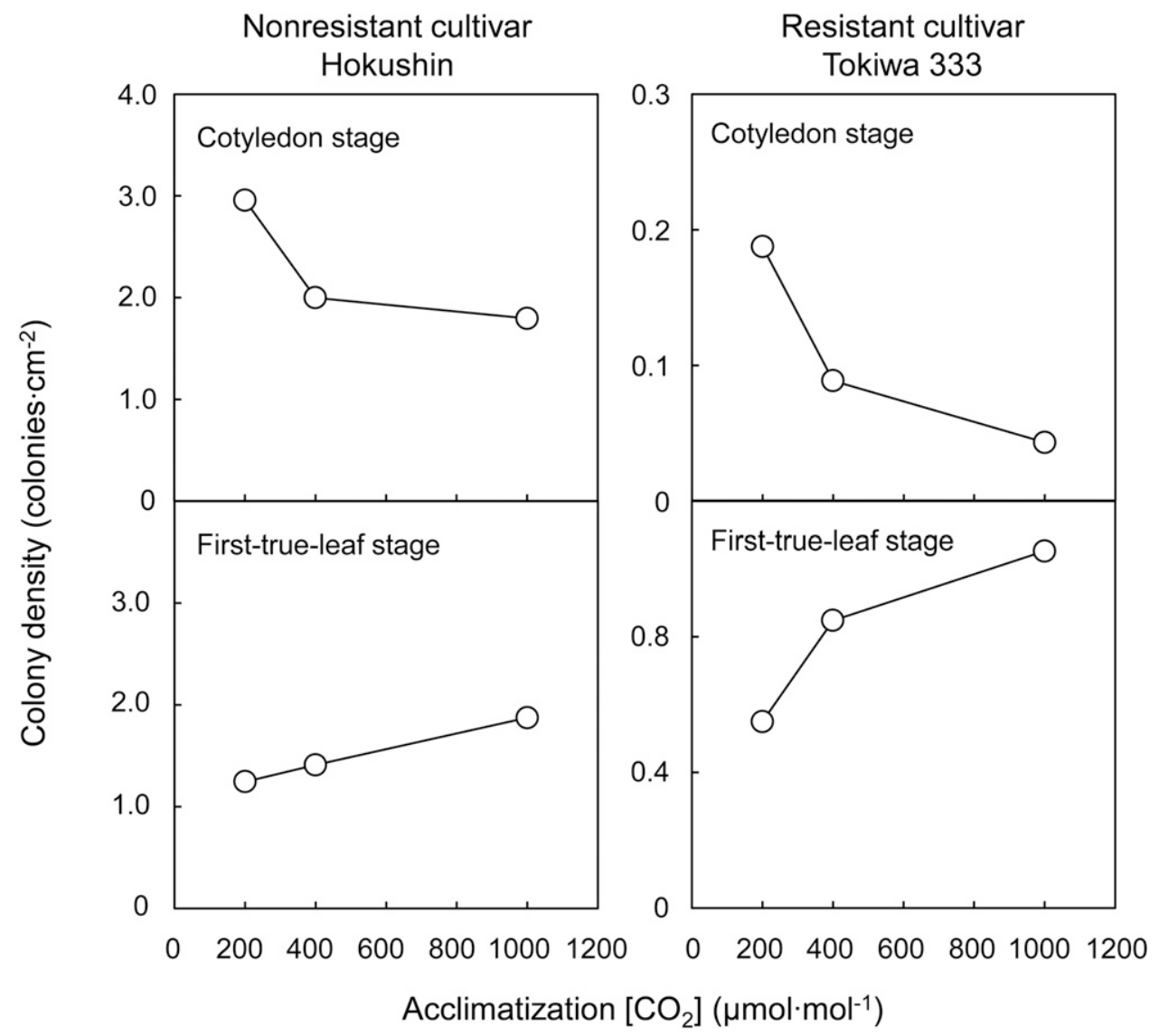

Fig. 1. Colony density of powdery mildew fungus $7 \mathrm{~d}$ after inoculation on seedlings of the nonresistant cultivar Hokushin and the resistant cultivar Tokiwa 333 acclimatized to reduced $\left(200 \mu \mathrm{mol} \cdot \mathrm{mol}^{-1}\right)$, ambient $\left(400 \mu \mathrm{mol} \cdot \mathrm{mol}^{-1}\right)$, or elevated $\left(1000 \mu \mathrm{mol} \cdot \mathrm{mol}^{-1}\right) \mathrm{CO}_{2}$ concentrations $\left(\left[\mathrm{CO}_{2}\right]\right)$. Average values of three trials are shown for the nonresistant cultivar. Average values of replicate plants are shown for the resistant cultivar (cotyledon stage, $\mathrm{n}=10$; first-true-leaf stage, $\mathrm{n}=15$ ). The results of one-way analysis of variance are shown in Tables 1 and 2 .

of $P$. xanthii on the adaxial leaf surfaces were counted $7 \mathrm{~d}$ after inoculation. The colony density was calculated by dividing the number of colonies by the leaf area.

Inoculation test at the first-true-leaf stage. Plants were inoculated at the first-true-leaf stage in three sequential trials with 'Hokushin' and one trial with 'Tokiwa 333', simultaneous with the third trial of 'Hokushin'. The growth conditions were the same as in the cotyledonstage test. When the first true leaf had expanded and the second true leaf had begun to emerge, 10 seedlings of 'Hokushin' in trials 1 and 2, 15 of 'Hokushin' in trial 3, and 15 of 'Tokiwa 333' were inoculated as above at $0.74 \times 10^{6}$ spores/ $\mathrm{mL}$ in trial $1,1.42 \times 10^{6}$ spores $/ \mathrm{mL}$ in trial 2 , and $0.68 \times 10^{6}$ spores $/ \mathrm{mL}$ in trial 3 .

Determination of leaf properties. The fresh weight, dry mass, and leaf area of 10 seedlings from each $\left[\mathrm{CO}_{2}\right]$ treatment in the cotyledon test and 15 seedlings in the first-true-leaf test were measured, and leaf mass per area (LMA) and dry matter content (DMC) were calculated. The $\mathrm{C}$ and $\mathrm{N}$ contents were also determined with a CN Elemental Analyzer (2400 Series II; PerkinElmer Inc., Waltham, MA). All properties were measured once.

Statistical analysis. The effects of $\left[\mathrm{CO}_{2}\right]$ on colony density were determined by oneway analysis of variance (ANOVA) for each trial. The LMA, DMC, and $\mathrm{C}$ and $\mathrm{N}$ contents were also compared by one-way ANOVA.

Table 1. Results of one-way analysis of variance in trials of nonresistant cultivar Hokushin and resistant cultivar Tokiwa 333 to test the effects of $\mathrm{CO}_{2}$ concentrations on powdery mildew colony density at the cotyledon and first-true-leaf stages.

\begin{tabular}{llcccc}
\hline & & \multicolumn{3}{c}{ Nonresistant } & Resistant \\
\cline { 2 - 5 } & & Trial 1 & Trial 2 & Trial 3 & 2 \\
Cotyledon stage & $\mathrm{df}$ & 2 & 2 & 2 & 13.6 \\
& $F$ & 8.8 & 59.8 & 15.8 & $<0.001$ \\
First-true-leaf stage & $P$ & 0.001 & $<0.001$ & $<0.001$ & 2 \\
& $\mathrm{df}$ & 2 & 2 & 2 & 7.5 \\
& $F$ & 13.2 & 16.0 & $<0.001$ & 0.002 \\
\hline
\end{tabular}

Cotyledon stage, $\mathrm{n}=10$, all trials; first-true-leaf stage, $\mathrm{n}=10$, trials 1 and $2 ; \mathrm{n}=15$, trial 3 and resistant cultivar.

The interaction effect of $\left[\mathrm{CO}_{2}\right]$ and cultivar (in trial 3) on colony density was determined by two-way ANOVA.

\section{Results}

Acclimatization $\left[\mathrm{CO}_{2}\right]$ had a significant effect on $P$. xanthii colony density at both the cotyledon and first-true-leaf stages (Fig. 1; Table 1), but the trend differed between stages. The difference in density of spore suspension between the trials probably did not influence the results of inoculation tests, because there were no significant relationships between the spore suspension density and the colony density (details not shown).

In the cotyledon test, the colony density decreased as acclimatization $\left[\mathrm{CO}_{2}\right]$ increased, but the slope was greater below ambient $\left[\mathrm{CO}_{2}\right]$ than above (Fig. 1). In the nonresistant 'Hokushin', the colony density on seedlings acclimatized to reduced and elevated $\left[\mathrm{CO}_{2}\right]$ was $1.48 \times$ and $0.90 \times$, respectively, that of ambient $\left[\mathrm{CO}_{2}\right]$. In the resistant 'Tokiwa 333', it was $2.12 \times$ and $0.49 \times$, respectively. There was a significant interaction between the effects of acclimatization $\left[\mathrm{CO}_{2}\right]$ and cultivar on colony density (Table 2): the effect of acclimatization $\left[\mathrm{CO}_{2}\right]$ was greater in the resistant cultivar than in the nonresistant cultivar, although the colony density was significantly lower in the nonresistant cultivar because of the difference in the initial level of resistance (Fig. 1).

In the first-true-leaf test, the colony density instead increased as acclimatization 
$\left[\mathrm{CO}_{2}\right]$ increased (Fig. 1). In the nonresistant 'Hokushin', the colony density of seedlings acclimatized to reduced and elevated $\left[\mathrm{CO}_{2}\right]$ was $0.88 \times$ and $1.33 \times$, respectively, that of ambient $\left[\mathrm{CO}_{2}\right]$. In the resistant 'Tokiwa 333', it was $0.65 \times$ and $1.24 \times$, respectively. Again, there was a significant interaction between the effects of acclimatization $\left[\mathrm{CO}_{2}\right]$ and cultivar on colony density (Table 2): the effect of acclimatization $\left[\mathrm{CO}_{2}\right]$ was again

Table 2. Results of two-way analysis of variance of effects of cultivar and $\mathrm{CO}_{2}$ concentrations $\left(\left[\mathrm{CO}_{2}\right]\right)$ on powdery mildew colony density in seedlings of nonresistant cultivar Hokushin (trial 3) and resistant cultivar Tokiwa 333 (tested simultaneously) at the cotyledon and first-true-leaf stages.

\begin{tabular}{llrrr}
\hline & & df & $F$ & $P$ \\
\hline Cotyledon stage & Cultivar & 1 & 663.9 & $<0.001$ \\
& {$\left[\mathrm{CO}_{2}\right]$} & 2 & 20.5 & $<0.001$ \\
First-true-leaf stage & Cultivar $\times\left[\mathrm{CO}_{2}\right]$ & 2 & 11.0 & $<0.001$ \\
& Cultivar & 1 & 41.0 & $<0.001$ \\
& {$\left[\mathrm{CO}_{2}\right]$} & 2 & 8.82 & $<0.001$ \\
& Cultivar $\times\left[\mathrm{CO}_{2}\right]$ & 2 & 4.96 & 0.009 \\
\hline
\end{tabular}

Cotyledon stage, $\mathrm{n}=10$; first-true-leaf stage, $\mathrm{n}=15$. greater in the resistant cultivar than in the nonresistant cultivar (Fig. 1).

At both growth stages, there were significant effects of $\left[\mathrm{CO}_{2}\right]$ on LMA, DMC, and $\mathrm{C}$ and $\mathrm{N}$ contents in both cultivars (Fig. 2). LMA and DMC increased as acclimatization $\left[\mathrm{CO}_{2}\right]$ increased. $\mathrm{C}$ increased and $\mathrm{N}$ decreased as acclimatization $\left[\mathrm{CO}_{2}\right]$ increased. The $\mathrm{C}: \mathrm{N}$ ratio thereby increased as acclimatization $\left[\mathrm{CO}_{2}\right]$ increased (data not shown). DMC and $\mathrm{C}$ were greater at the first-true-leaf stage than at the cotyledon stage $(P<0.001$, details not shown).

\section{Discussion}

The results show that the development of powdery mildew is affected by acclimatization

\section{Cotyledon stage}

First-true-leaf stage

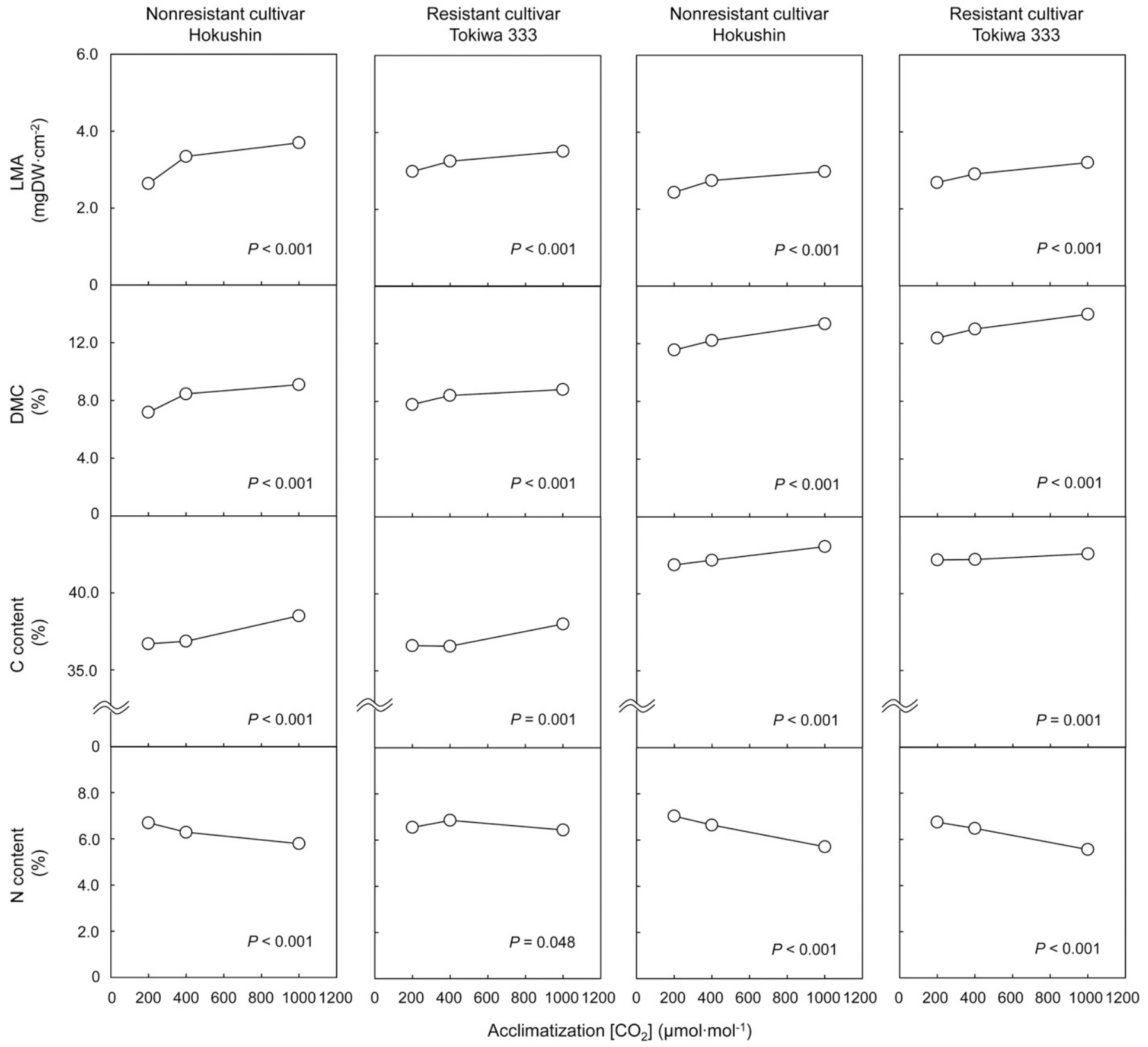

Fig. 2. Leaf mass per area (LMA), dry matter content (DMC), and carbon (C) and nitrogen (N) contents of nonresistant cultivar Hokushin and resistant cultivar

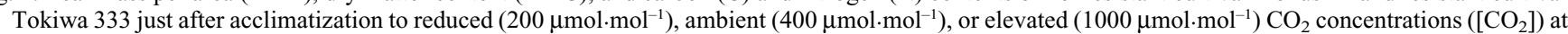
the cotyledon or first-true-leaf stage. Average values of replicate plants are shown (cotyledon stage, $\mathrm{n}=10$; first-true-leaf stage, $\mathrm{n}=15$ ). 
$\left[\mathrm{CO}_{2}\right]$ at both lower and higher than ambient levels through changes in host-plant properties. The increases in $\left[\mathrm{CO}_{2}\right]$ during the dark period in each treatment group probably did not influence the leaf properties of the acclimated seedlings, because the increases occurred within the range in which dark respiration was generally not influenced (Jahnke and Krewitt, 2002). Because the powdery mildew fungus invades the leaf through the epidermis, not through the stomata, the differences in colony density between $\left[\mathrm{CO}_{2}\right]$ treatments are related to the penetration and development of the fungus. The effect of acclimatization $\left[\mathrm{CO}_{2}\right]$ on host-plant susceptibility was greater at lower $\left[\mathrm{CO}_{2}\right]$ than at higher $\left[\mathrm{CO}_{2}\right]$ at both leaf stages. However, the effect was positive at the cotyledon stage and negative at the first-trueleaf stage. Previous studies of the effect of $\left[\mathrm{CO}_{2}\right]$ on host-plant susceptibility using a variety of materials and methods (e.g., $\left[\mathrm{CO}_{2}\right]$, growing condition, host plant, and foliar disease) reported conflicting results (Eastburn et al., 2011; Lake and Wade, 2009). This result reveals different effects of $\left[\mathrm{CO}_{2}\right]$ between growing stages in the same plant species. The difference may be due to differences in structure and physiological functions between cotyledons and true leaves, and may partly explain the previous conflicting results.

The LMA and $\mathrm{N}$ contents of the host plants are generally involved in plant susceptibility to pathogens (Eastburn et al., 2011; Mathur et al., 2013; McElrone et al., 2005). An increase in LMA and a decrease in N content and the consequent increase in the $\mathrm{C}: \mathrm{N}$ ratio might reduce susceptibility to powdery mildew (Feng et al., 2009; Itagaki et al., 2014; Mathur et al., 2013; McElrone et al., 2005; Wright and Cannon, 2001). These relationships between host-plant properties and plant susceptibility support the results in the cotyledon test but not in the first-true-leaf test. Thus, the change in plant susceptibility cannot easily be explained by the LMA, N content, and $\mathrm{C}: \mathrm{N}$ ratio at both stages, and therefore, other properties must be involved.

The increase in DMC and C contents may have increased the host-plant susceptibility through an increase in $\mathrm{C}$ sources for the development of powdery mildew (Abood and Lösel, 2003; Ayres et al., 1996). C sources are the main components taken up by powdery mildews (Hall and Williams, 2000). Although there was no interaction effect between these properties and growth stage (details not shown), the absolute values of these contents were higher in the first true leaves than in the cotyledons. That is, although the increase in these values did not explain the increase in susceptibility, the higher range of values at the first-true-leaf stage may have increased the susceptibility. This inability to clarify why the effect of acclimatization $\left[\mathrm{CO}_{2}\right]$ on host-plant susceptibility differed between the growth stages implies that several factors related to host-plant susceptibility may interact in a complex manner.

The effects of acclimatization $\left[\mathrm{CO}_{2}\right]$ on the susceptibility of the resistant cultivar Tokiwa 333 at both leaf stages were similar to but greater than those of Hokushin. This greater effect may indicate that 'Tokiwa 333' was more responsive to the effects of acclimatization $\left[\mathrm{CO}_{2}\right]$. However, the basic mechanism for the difference in resistance between 'Hokushin' and 'Tokiwa 333' is still unknown. To elucidate the relationship between $\left[\mathrm{CO}_{2}\right]$ and host-plant susceptibility, the physiological responses and corresponding behavior of the pathogen should be more closely examined in a wider range of cultivars.

In conclusion, these results reveal that acclimatization $\left[\mathrm{CO}_{2}\right]$ both below and above ambient levels affect the development of powdery mildew. The effect on host-plant susceptibility tended to be greater at reduced $\left[\mathrm{CO}_{2}\right]$ than at elevated $\left[\mathrm{CO}_{2}\right]$. Thus, the effect of $\left[\mathrm{CO}_{2}\right]$ on disease development through host-plant properties must be considered, especially under $\mathrm{CO}_{2}$ starvation condition. The difference in effect between the cotyledon and first-true-leaf stages suggests that the growth stage must be specified when the effects of environmental factors on plantpathogen interactions are described.

\section{Literature Cited}

Abood, J.K. and D.M. Lösel. 2003. Changes in carbohydrate composition of cucumber leaves during the development of powdery mildew infection. Plant Pathol. 52:256-265.

Ayres, P.G., M.C. Press, and P.T. Spencer-Phillips. 1996. Effects of pathogens and parasitic plants on source-sink relationships, p. 479-499. In: E. Zamski and A.A. Schaffer (eds.). Photoassimilate distribution in plants and crops. Marcel Dekker, New York, NY.

Bazzaz, F.A., N.R. Chiariello, P.D. Coley, and L.F. Pitelka. 1987. Allocating resources to reproduction and defense. Bioscience 37:58-67.

Bryant, J.P., F.S. Chapin, III, and D.R. Klein. 1983. Carbon nutrient balance of boreal plants in relation to vertebrate herbivory. Oikos 40:357-368

Eastburn, D.M., A.J. McElrone, and D.D. Bilgin. 2011. Influence of atmospheric and climatic change on plant-pathogen interactions. Plant Pathol. 60:54-69.

Feng, Y.L., Y.B. Lei, R.F. Wang, R.M. Callaway, A. Valiente-Banuet, Y.P. Li, and Y.L. Zheng. 2009. Evolutionary tradeoffs for nitrogen allocation to photosynthesis versus cell walls in an invasive plant. Proc. Natl. Acad. Sci. USA 106:18531856.

Gerhart, L.M. and J.K. Ward. 2010. Plant responses to low $\left[\mathrm{CO}_{2}\right]$ of the past. New Phytol. 188:674 695.

Hall, J.L. and L.E. Williams. 2000. Assimilate transport and partitioning in fungal biotrophic interactions. Funct. Plant Biol. 27:549-560.

Itagaki, K., T. Shibuya, M. Tojo, R. Endo, and Y. Kitaya. 2014. Atmospheric moisture influences on conidia development in Podosphaera xanthii through host-plant morphological responses. Eur. J. Plant Pathol. 138:113-121.

Jahnke, S. and M. Krewitt. 2002. Atmospheric $\mathrm{CO}_{2}$ concentration may directly affect leaf respiration measurement in tobacco, but not respiration itself. Plant Cell Environ. 25:641-651.

Kläring, H.P., C. Hauschild, A. Heißner, and B. Bar-Yosef. 2007. Model-based control of $\mathrm{CO}_{2}$ concentration in greenhouses at ambient levels increases cucumber yield. Agr. For. Meteorol. 143:208-216.

Kobayashi, T., K. Ishiguro, T. Nakajima, H.Y. Kim, M. Okada, and K. Kobayashi. 2006. Effects of elevated atmospheric $\mathrm{CO}_{2}$ concentration on the infection of rice blast and sheath blight. Phytopathology 96:425-431.

Lake, J.A. and R.N. Wade. 2009. Plant-pathogen interactions and elevated $\mathrm{CO}_{2}$ : Morphological changes in favour of pathogens. J. Expt. Bot. 60:3123-3131.

Manning, W.J. and A. Tiedemann. 1995. Climate change: Potential effects of increased atmospheric carbon dioxide $\left(\mathrm{CO}_{2}\right)$, ozone $\left(\mathrm{O}_{3}\right)$, and ultraviolet-B (UV-B) radiation on plant diseases. Environ. Pollut. 88:219-245.

Mathur, P., E. Sharma, S.D. Singh, A.K. Bhatnagar, V.P. Singh, and R. Kapoor. 2013. Effect of elevated $\mathrm{CO}_{2}$ on infection of three foliar diseases in oilseed Brassica juncea. J. Plant Pathol. 95:135-144.

McElrone, A.J., C.D. Reid, K.A. Hoye, E. Hart, and R.B. Jackson. 2005. Elevated $\mathrm{CO}_{2}$ reduces disease incidence and severity of a red maple fungal pathogen via changes in host physiology and leaf chemistry. Glob. Change Biol. 11:1828-1836.

Mortensen, L.M. 1987. Review: $\mathrm{CO}_{2}$ enrichment in greenhouses. Crop responses. Sci. Hort. 33:1-25.

Nilsen, S., K. Hovland, C. Dons, and S.P. Sletten. 1983. Effect of $\mathrm{CO}_{2}$ enrichment on photosynthesis, growth and yield of tomato. Sci. Hort. 20:1-14.

Sage, R.F. 1995. Was low atmospheric $\mathrm{CO}_{2}$ during the Pleistocene a limiting factor for the origin of agriculture? Glob. Change Biol. 1:93-106.

Sage, R.F. and S.A. Cowling. 1999. Implications of stress in low $\mathrm{CO}_{2}$ atmospheres of the past: Are today's plants too conservative for a high $\mathrm{CO}_{2}$ world? p. 289-305. In: Y. Luo and H.A Mooney (eds.). Carbon dioxide and environmental stress. Academic Press, San Diego, CA.

Sánchez-Guerrero, M.C., P. Lorenzo, E. Medrano, N. Castilla, T. Soriano, and A. Baille. 2005. Effect of variable $\mathrm{CO}_{2}$ enrichment on greenhouse production in mild winter climates. Agr. For. Meteorol. 132:244-252.

Shibuya, T., K. Itagaki, M. Tojo, R. Endo, and Y. Kitaya. 2011. Fluorescent illumination with high red-to-far-red ratio improves resistance of cucumber seedlings to powdery mildew. HortScience 46:429-431.

Strengbom, J. and P.B. Reich. 2006. Elevated $\left[\mathrm{CO}_{2}\right]$ and increased $\mathrm{N}$ supply reduce leaf disease and related photosynthetic impacts on Solidago rigida. Oecologia 149:519-525.

Wright, I.J. and K. Cannon. 2001. Relationships between leaf lifespan and structural defences in a low-nutrient, sclerophyll flora. Funct. Ecol. 15:351-359. 